\title{
ARTICLE
}

\section{Determination of the Trace Element Contents of Fruit Juice Samples by ICP OES and ICP-MS}

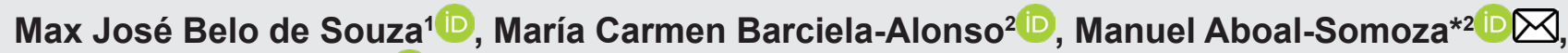 \\ Pilar Bermejo-Barrera² ${ }^{\text {iD }}$
}

${ }^{1}$ Instituto Federal de Educação, Ciência e Tecnologia do Espírito Santo. Coordenadoria de Licenciatura em Química. Avenida Morobá, 248, Bairro Morobá, 29192-733, Aracruz, ES, Brazil

${ }^{2}$ Universidade de Santiago de Compostela; Department of Analytical Chemistry, Nutrition and Bromatology. Avda. Las Ciencias, s/n, 15782, Santiago de Compostela (La Coruña), Spain

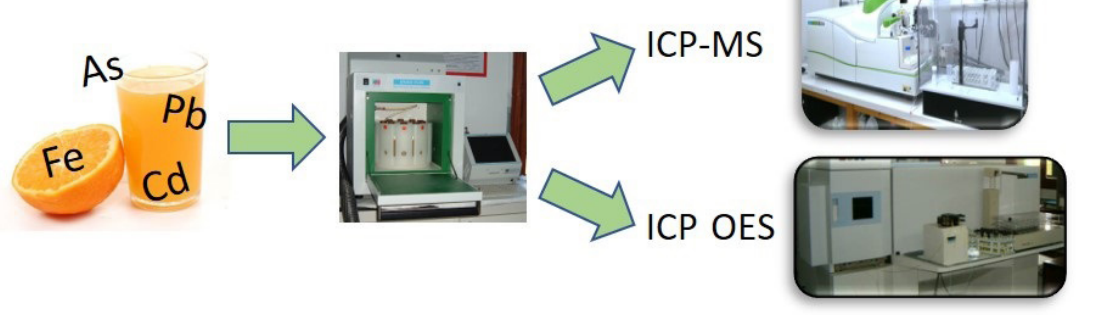

Fruit juices were analysed for their contents in a series of essential and toxic elements (Al, As, Ca, Cd, Co, Cr, $\mathrm{Cu}, \mathrm{Fe}, \mathrm{Mg}, \mathrm{Mn}, \mathrm{Na}, \mathrm{Ni}, \mathrm{Pb}, \mathrm{V}, \mathrm{Sb}, \mathrm{Mo}$ and $\mathrm{Zn}$ ). Samples were subjected to microwave-assisted acid digestion $\left(\mathrm{HNO}_{3} / \mathrm{H}_{2} \mathrm{O}_{2}\right)$, and analytes were determined by inductively coupled plasma optical emission spectrometry (ICP OES), in axial mode, or by inductively coupled plasma mass spectrometry (ICP-MS), with kinetic energy discrimination, using ${ }^{103} \mathrm{Rh}$ and ${ }^{89} \mathrm{Y}$ as internal standards. The methods were validated, showing good precision (relative standard deviations $<10 \%$ ), linearity and mean analytical recovery values (89 to $103 \%$ ). The ICP OES instrumental limits of detection (LODs) were between $0.3 \mu \mathrm{g} \mathrm{L} \mathrm{L}^{-1}$ (for Mg) and $1.5 \mu \mathrm{g}$ $\mathrm{L}^{-1}$ (for $\mathrm{Ca}$ ), whereas ICP-MS instrumental LODs varied from $2 \mathrm{ng} \mathrm{L}^{-1}$ (for Co, Mo and V) to $5.7 \mu \mathrm{L} \mathrm{L}^{-1}$ (for $\mathrm{Na}$ ). Some toxic elements (As and $\mathrm{Sb}$ ) were not detected in the fruit juices analyzed, Cd concentrations were below the maximum permitted level established by Brazilian and European regulations and only in one sample the $\mathrm{Pb}$ concentration $\left(61.7 \mu \mathrm{g} \mathrm{L}^{-1}\right)$ exceeded current legal limits. Besides, essential elements such as $\mathrm{Ca}$, Mg and $\mathrm{Na}$ were in high concentrations in the samples analyzed.

Keywords: fruit juice, toxic and essential trace elements, ICP OES, ICP-MS.

\section{INTRODUCTION}

The World Health Organization [1], in its report on diet, nutrition and chronic diseases prevention, considers that a diet with abundant ingestion of fruits and vegetables is essential for chronic diseases prevention. This current call for a healthy life and nutrition care also produces a demand of fruit juices, nectars and concentrates that are foods with nutritional and sensory characteristics that resemble foodstuff in natura.

Cite: de Souza, M. J. B.; Barciela-Alonso, M. C.; Aboal-Somoza, M.; Bermejo-Barrera, P. Determination of the Trace Element Contents of Fruit Juice Samples by ICP OES and ICP-MS. Braz. J. Anal. Chem. 2022, 9 (35), pp 49-61. http://dx.doi.org/10.30744/ brjac.2179-3425.AR-87-2021 
Fruits and juices contain mineral elements, carbohydrates, proteins, are cholesterol free and also have vitamins, carotenoids, essential micronutrients, folate and natural antioxidants. Among the trace elements, $\mathrm{Ca}, \mathrm{Fe}, \mathrm{Mg}, \mathrm{Zn}, \mathrm{K}$ and $\mathrm{Na}$ are essential nutrients for the organism, because they participate in the constitution of bones, teeth, muscles, blood and nerve cells among others [2].

Moreover, fruits and juices may contain potentially toxic elements such as As, $\mathrm{Cd}, \mathrm{Pb}$ or $\mathrm{Hg}$. These elements may be present due to absorption processes of plants from soil, water, atmospheric air, manufacturing processes of juices and migration processes from packaging. Therefore, regulatory organizations responsible of food safety pay special attention to these elements. Their contents in fruit juices are included in regulations such as the Codex Alimentarius [3] and European Commission Regulations [4,5], which set $0.03 \mathrm{mg} \mathrm{kg}^{-1}$ as the Maximum Permitted Level (MPL) for Pb in fruit juices and $0.05 \mathrm{mg} \mathrm{kg}^{-1}$ in fruit juices exclusively from berries and other small fruits and $0.02 \mathrm{mg} \mathrm{kg}^{-1}$ of Cd in drinks (including fruit juices) for infants and young children. The Brazilian Health Regulatory Agency (ANVISA) [6] established a maximum allowed limit of $0.05 \mathrm{mg} \mathrm{kg}^{-1}$ for $\mathrm{Pb}$ in fruit juices, $0.05 \mathrm{mg} \mathrm{kg}^{-1}$ for Cd and $0.10 \mathrm{mg} \mathrm{kg}^{-1}$ for As in fruit juices and nectars.

The most used techniques to determine the total concentration of metals in fruit juices are flame atomic absorption spectrometry (FAAS), graphite furnace atomic absorption spectrometry (GFAAS) [7], inductively coupled plasma optical emission spectrometry (ICP OES) [8-10], inductively coupled plasma mass spectrometry (ICP-MS) [9-12], and for the speciation analysis, high performance liquid chromatography (HPLC) coupled to ICP-MS [10,13] and ICP-MS/MS [14]. Hafez et al. [15] combined a supramolecular solvent-based liquid-phase microextraction method with spectrophotometric measurements at $550 \mathrm{~nm}$ for Al determination in water and fruit juices. Jedryczko et al. [16] determined the labile species fraction of Cd, $\mathrm{Pb}$ and $\mathrm{Zn}$ in apple beverages, including apple juices, by anodic stripping chronopotentiometry. FAAS is usually, restricted to the determination of major elements due to its low sensitivity. Although, GFAAS, ICP OES and ICP-MS are the most recommended techniques for trace elements analysis, ICP OES and ICPMS are the techniques of choice due to their well-known advantages of sensitivity, selectivity and multielemental analysis capacities.

Sample preparation procedures for fruits or fruit juices analysis include calcination $[17,18]$ and wet digestion in open or closed systems such as hot plate [19] or digestion block [7]. The use of microwave heating [14,20-23], which reduces drastically the time required for the pretreatment of the sample is today the most common technique. The reagents used in digestions are often acids with strong oxidizing power for the sample organic matter destruction, such as $\mathrm{HNO}_{3}$, which has been used alone [23-25], or combined with $\mathrm{H}_{2} \mathrm{SO}_{4}$ [26], $\mathrm{HClO}_{4}$ [19] or $\mathrm{H}_{2} \mathrm{O}_{2}[7,20,21,27]$.

In previous studies reported in the literature, high levels of trace elements were found in samples of commercial fruit juices. Savić et al. [8] obtained concentration levels of $1.19 \mathrm{mg} \mathrm{L}^{-1} \mathrm{~Pb}$ in clear orange juices and Fathabada et al. [22] found $\mathrm{Pb}$ values up to $66.1 \mathrm{\mu g} \mathrm{kg}^{-1}$ in fruit juices and Kowalska et al. [12] found up to $0.067 \mathrm{mg} \mathrm{kg}^{-1}$ of $\mathrm{Pb}$ in black currant nectars, and As values up to $0.149 \mathrm{mg} \mathrm{kg}^{-1} \mathrm{in}$ apple juices and $0.144 \mathrm{mg} \mathrm{kg}^{-1}$ in orange juices. Other authors, such as Demir et al. [23], reported Pb concentrations of $0.121 \mathrm{mg} \mathrm{L}^{-1}$ in apricot nectar and $0.135 \mathrm{mg} \mathrm{L}^{-1}$ in peach nectar and Mohamed et al. [28] reported a value of $8.07 \mathrm{mg} \mathrm{L}^{-1}$ of $\mathrm{Pb}$ in mango juice purchased in a Yemeni market.

The main objective of this study was to determinate trace elements in fruit juices. To achieve this objective, the sample was prepared using a microwave-assisted acid digestion, followed by ICP OES or ICP-MS determination.

\section{MATERIALS AND METHODS Instrumentation}

Major elements determination in acid-digested samples was performed using an Optima 3300 DV inductively coupled plasma atomic emission spectrometer equipped with an AS 91 autosampler and a Gem-Cone crossflow nebulizer (Perkin Elmer, Waltham, MA, USA). Trace elements in digested samples were determined using a Perkin Elmer NexIon 300X ICP-MS instrument equipped with a SeaFast SC2 DX 
autosampler (Elemental Scientific, Omaha, NB, USA). Sample digestion was carried out using a microwave oven Ethos Plus MW Labstation with $100 \mathrm{~mL}$ closed Teflon vessels and Teflon covers, HTC adapter plate and HTC safety springs (Milestone, Sorisole, Italy).

\section{Reagents}

Nitric acid 69\% Hiperpur (Applichem Panreac - ITW Companies, Barcelona, Spain); $\mathrm{H}_{2} \mathrm{O}_{2} 33 \%$ ACS, ISO (Applichem Panreac) and ultrapure water, resistivity $18 \mathrm{M} \Omega \mathrm{cm}$ (Millipore, Bedford, Maryland, USA). ICP OES calibration solutions were prepared with standard monoelemental solutions of $1.000 \mu \mathrm{gL} \mathrm{mL}^{-1}$ of Zn (Scharlau, Barcelona, Spain), Ca, Mg, (CertiPUR ${ }^{\circledR}$ - MERCK, Darmstadt, Germany). ICP-MS calibration solutions were prepared from a multielemental standard solution containing Al, As, Cd, Co, Cr, Cu, Fe, Mn, $\mathrm{Na}, \mathrm{Ni}, \mathrm{Pb}$ and $\mathrm{V}$, each element at $10 \mathrm{\mu g} \mathrm{mL}^{-1}$ (PerkinElmer Pure Plus) and individual standard solutions of $1,000 \mu \mathrm{g} \mathrm{mL}{ }^{-1}$ of $\mathrm{Sb}$ and Mo (CertiPUR ${ }^{\circledR}$ - MERCK). Y and Rh were used as internal standards at concentrations of $10 \mu \mathrm{g} \mathrm{L}^{-1}$. This solution was prepared from a $10 \mathrm{mg} \mathrm{L}^{-1}$ standard solution of $\mathrm{Y}$ (Perkin Elmer Pure Plus) and a $1000 \mathrm{mg} \mathrm{L}^{-1}$ standard solution of Rh (Fluka TraceCERT ${ }^{\mathrm{TM}}$ ).

\section{Samples}

The 21 samples analysed in this study include 16 fruit juices (orange, tangerine, red berries, peach, pineapple, apple and grape, mango and orange) and 2 nectars (passion fruit and purple pear nectar) of different brands bought in supermarkets in Spain and Portugal, and 2 orange juices and one lemon juice squeezed in the laboratory (denoted, respectively, as "Orange 4","Orange 5" and "Lemon"). These samples were treated in a manual domestic squeezer, where most of the solid fraction was retained in the filter and therefore an homogeneous sample was obtained.

\section{Microwave-assisted acid digestion procedure}

Just before being sampled, each commercial juice bottle was manually shaken for homogenization. Aliquots of $2.5 \mathrm{~mL}$ of the homogenized juice samples were transferred into a $100 \mathrm{~mL}$ high pressure Teflon vessel with $3.0 \mathrm{~mL}$ of $69 \% \mathrm{HNO}_{3}, 1.0 \mathrm{~mL}$ of $33 \% \mathrm{H}_{2} \mathrm{O}_{2}$ and $2.0 \mathrm{~mL}$ of ultrapure water. Closed vessels were introduced in the microwave oven and subjected to a four steps temperature program for digestion. Firstly, the temperature was linearly increased from room temperature to $90^{\circ} \mathrm{C}$ with increasing the power up to $1000 \mathrm{~W}$ for $2.5 \mathrm{~min}$. The temperature was then elevated to $140^{\circ} \mathrm{C}$ in $6 \mathrm{~min}$ (power $1000 \mathrm{~W}$ ). Finally, the temperature was increased to $180^{\circ} \mathrm{C}$ in five minutes $(800 \mathrm{~W})$, maintaining these conditions for $15 \mathrm{~min}$. The digestion procedure was carried out in triplicate for each sample. Besides, a sample blank digestion was prepared for each series of digestions using ultrapure water instead of sample.

Both digested samples and blanks were diluted to $25 \mathrm{~mL}$ with ultrapure water and analysed by ICP OES or ICP-MS after appropriate dilution.

\section{Trace element determination by ICP OES and ICP-MS}

Trace element determination in the acid-digested samples were carried out by ICP OES and ICP-MS. Instrumental conditions for ICP OES and ICP-MS, as well as the concentration ranges used for calibration, are shown in Tables I and II, respectively. Samples were analysed in quintuplicate with an integration time of $5 \mathrm{~s}$ by ICP OES and in triplicate with an integration time of $50 \mathrm{~ms}$ by ICP-MS. ICP-MS polyatomic interferences were minimized with a helium collision cell using helium flows of $1 \mathrm{~mL} \mathrm{~min}^{-1}$ (Kinetic Energy Discrimination, KED 1) or $4 \mathrm{~mL} \mathrm{~min}^{-1}$ (KED 4). 
Table I. Instrumental operational conditions for ICP OES

\begin{tabular}{|c|c|}
\hline Component/Parameter & Type/Value/Mode \\
\hline RF Power & $1300 \mathrm{~W}$ \\
\hline Nebulizer & Cross Flow GemTip \\
\hline Plasma gas flow & $16.0 \mathrm{~L} \mathrm{~min}^{-1}$ \\
\hline Auxiliary gas flow & $0.5 \mathrm{~L} \mathrm{~min}^{-1}$ \\
\hline Nebulizer gas flow & $0.8 \mathrm{~L} \mathrm{~min}^{-1}$ \\
\hline Sample uptake rate & $1.5 \mathrm{~mL} \mathrm{~min}-1$ \\
\hline Integration time & $5 \mathrm{~s}$ \\
\hline Replicates per sample & 5 \\
\hline Mode of operation & Axial \\
\hline Wavelength & 393.366 nm (Ca); 279.553 nm (Mg); 206.205 nm (Zn) \\
\hline Calibration interval & $0.050-50 \mathrm{mg} \mathrm{L}^{-1}(\mathrm{Ca}, \mathrm{Mg}) ; 0.050-1.5 \mathrm{mg} \mathrm{L}^{-1}(\mathrm{Zn})$ \\
\hline
\end{tabular}

Table II. Instrumental operational conditions for ICP-MS

\begin{tabular}{|c|c|}
\hline Component/Parameter & Type/Value/Mode \\
\hline Nebulizer & PFA-ST Microflow Nebulizer \\
\hline Spray chamber & PC $^{3}$ Peltier Cooler - Quartz cyclonic \\
\hline Triple cone interface material & Nickel \\
\hline Plasma gas flow & $16.0 \mathrm{~L} \mathrm{~min}^{-1}$ \\
\hline Auxiliary gas flow & $1.2 \mathrm{~L} \mathrm{~min}^{-1}$ \\
\hline Nebulizer gas flow & $0.94 \mathrm{~L} \mathrm{~min}^{-1}$ \\
\hline Sample uptake rate & $400 \mu \mathrm{L} \min ^{-1}$ \\
\hline RF power & $1600 \mathrm{~W}$ \\
\hline Integration time & $50 \mathrm{~ms}$ \\
\hline Replicates per sample & 3 \\
\hline Mode of operation & $\begin{array}{l}\text { KED (Kinetic Energy Discrimination) } \\
1 \mathrm{~mL} \mathrm{~min}{ }^{-1} \mathrm{He}\left({ }^{27} \mathrm{Al},{ }^{111} \mathrm{Cd},{ }^{63} \mathrm{Cu},{ }^{55} \mathrm{Mn},{ }^{98} \mathrm{Mo},{ }^{208} \mathrm{~Pb}\right) \\
4 \mathrm{~mL} \mathrm{~min}{ }^{-1} \mathrm{He}\left({ }^{75} \mathrm{As},{ }^{59} \mathrm{Co},{ }^{52} \mathrm{Cr},{ }^{54} \mathrm{Fe},{ }^{23} \mathrm{Na},{ }^{60} \mathrm{Ni},{ }^{121} \mathrm{Sb},{ }^{51} \mathrm{~V}\right)\end{array}$ \\
\hline Isotopes & $\begin{array}{l}{ }^{27} \mathrm{Al},{ }^{75} \mathrm{As},{ }^{111} \mathrm{Cd},{ }^{59} \mathrm{Co},{ }^{52} \mathrm{Cr},{ }^{63} \mathrm{Cu},{ }^{54} \mathrm{Fe},{ }^{55} \mathrm{Mn},{ }^{23} \mathrm{Na},{ }^{60} \mathrm{Ni},{ }^{208} \mathrm{~Pb}, \\
{ }^{98} \mathrm{Mo},{ }^{121} \mathrm{Sb},{ }^{51} \mathrm{~V}\end{array}$ \\
\hline Calibration interval & $0.5-100.0 \mu \mathrm{g} \mathrm{L}^{-1}$ \\
\hline Internal standard & $10 \mu g \mathrm{~L}^{-1}\left({ }^{103} \mathrm{Rh},{ }^{89} \mathrm{Y}\right)$ \\
\hline
\end{tabular}

\section{Material cleaning and waste treatment}

All glassware and polypropylene bottles were immersed in a $10 \%(\mathrm{v} / \mathrm{v}) \mathrm{HNO}_{3}$ solution for $48 \mathrm{~h}$ followed by a minimum of three rinses with ultrapure water, dried and finally stored ready for use.

The waste generated throughout the work was collected in suitable containers and subsequently treated by the Waste Management Service of the University of Santiago de Compostela. 


\section{RESULTS AND DISCUSSION \\ Analytical performance}

The procedure for the determination of major and trace elements in digested juice samples by ICP OES and ICP-MS was evaluated for its linearity, accuracy, precision and detection and quantification limits (respectively, LOD and LOQ).

\section{Calibration}

To study the matrix effect, external calibration and standard addition methods were compared for element determination in digested fruit juices. Calibration standards and standard addition solutions were prepared by volume dilution with concentrations ranging from 0,050 to $15 \mathrm{mg} \mathrm{L}^{-1}$ for $\mathrm{Zn}$ and from 0,50 to $50 \mathrm{mg} \mathrm{L}^{-1}$ for $\mathrm{Ca}$ and $\mathrm{Mg}$ for analysis by ICP OES. Calibration solutions were prepared in $1 \%(\mathrm{v} / \mathrm{v}) \mathrm{HNO}_{3}$. A digested juice sample was used to prepare the solutions for the standard addition method. Each calibration solution was analyzed by quintuplicate using the measurement conditions shown in Table I.

In the determinations by ICP-MS, external calibration and standard addition were in the range 0.5-100 $\mu \mathrm{g} \mathrm{L}{ }^{-1}$ for $\mathrm{Al}, \mathrm{As}, \mathrm{Cd}, \mathrm{Co}, \mathrm{Cr}, \mathrm{Cu}, \mathrm{Fe}, \mathrm{Mn}, \mathrm{Na}, \mathrm{Ni}, \mathrm{Pb}, \mathrm{Mo}, \mathrm{Sb}$ and $\mathrm{V} .{ }^{89} \mathrm{Y}$ and ${ }^{103} \mathrm{Rh}$ were used as internal standards at a concentration of $10 \mu \mathrm{g} \mathrm{L}^{-1}$ and prepared in $1 \%(\mathrm{v} / \mathrm{v}) \mathrm{HNO}_{3}$. These solutions were analyzed using the instrumental conditions included in Table II.

The slopes obtained for all the elements studied as well as the correlation coefficients are shown in Table III. Slopes of external and standard addition calibration were compared using a t-test ( $5 \%$ significance level) [29] to evaluate the matrix effect. According to the results obtained, As, Co, $\mathrm{Na}, \mathrm{Ni}$ and $\mathrm{V}$ were measured using external calibration, and $\mathrm{Ca}, \mathrm{Cr}, \mathrm{Mg} \mathrm{Mn}, \mathrm{Mo}$ and $\mathrm{Zn}$ using the standard addition method. $\mathrm{Al}$ and $\mathrm{Sb}$ were analyzed using external calibration and ${ }^{103} \mathrm{Rh}$ as internal standard. For $\mathrm{Cd}, \mathrm{Cu}$ and $\mathrm{Pb}$ it was necessary to use the standard addition method with ${ }^{103} \mathrm{Rh}$ as internal standard, whereas Fe was determined using the standard addition method with ${ }^{89} \mathrm{Y}$ as internal standard.

Table III. Slopes and correlation coefficients of external calibrations and standard addition lines for ICP OES or ICP-MS determinations. Each internal standard used is indicated in brackets.

\begin{tabular}{lcccc}
\hline \multirow{2}{*}{ Element } & \multicolumn{2}{c}{ External calibration } & \multicolumn{2}{c}{ Standard addition } \\
\cline { 2 - 5 } & Slope & $\begin{array}{c}\text { Correlation } \\
\text { coefficient }(\mathbf{r})\end{array}$ & Slope & $\begin{array}{c}\text { Correlation } \\
\text { coefficient }(\mathbf{r})\end{array}$ \\
\hline $\mathrm{Al}\left({ }^{103} \mathrm{Rh}\right)$ & $4 \cdot 10^{-4}$ & 0.9998 & $4 \cdot 10^{-4}$ & 0.9998 \\
$\mathrm{As}$ & 260.3 & 0.9998 & 268.9 & 0.9978 \\
$\mathrm{Ca}^{\mathrm{a}}$ & 1145 & 0.9983 & 1126 & 0.9964 \\
$\mathrm{Cd}\left({ }^{103} \mathrm{Rh}\right)$ & $1.02 \cdot 10^{-2}$ & 1 & $1.0 \cdot 10^{-2}$ & 0.9979 \\
$\mathrm{Co}$ & 3842 & 0.9999 & 3986 & 0.9978 \\
$\mathrm{Cr}$ & 1467 & 0.9999 & 1581 & 0.9979 \\
$\mathrm{Cu}\left({ }^{103} \mathrm{Rh}\right)$ & $2.76 \cdot 10^{-2}$ & 0.9997 & $3.1 \cdot 10^{-2}$ & 0.9979 \\
$\mathrm{Fe}\left({ }^{89} \mathrm{Y}\right)$ & $2 \cdot 10^{-3}$ & 0.9998 & $2.2 \cdot 10^{-3}$ & 0.9975 \\
$\mathrm{Mg}{ }^{\mathrm{a}}$ & 2643.5 & 1 & 2675.8 & 0.9999 \\
$\mathrm{Mn}\left({ }^{89} \mathrm{Y}\right)$ & $4.9 \cdot 10^{-2}$ & 0.9997 & $5.6 \cdot 10^{-2}$ & 0.9978 \\
$\mathrm{Mo}$ & 12075 & 0.9950 & 20128 & 0.9983 \\
$\mathrm{Na}$ & 309.1 & 0.9961 & 314.2 & 0.9996 \\
\hline
\end{tabular}


Table III. Slopes and correlation coefficients of external calibrations and standard addition lines for ICP OES or ICP-MS determinations. Each internal standard used is indicated in brackets. (Continuation)

\begin{tabular}{lcccc}
\hline \multirow{2}{*}{ Element } & \multicolumn{2}{c}{ External calibration } & \multicolumn{2}{c}{ Standard addition } \\
\cline { 2 - 5 } & Slope & $\begin{array}{c}\text { Correlation } \\
\text { coefficient }(\mathbf{r})\end{array}$ & Slope & $\begin{array}{c}\text { Correlation } \\
\text { coefficient }(\mathbf{r})\end{array}$ \\
\hline $\mathrm{Ni}$ & 1130 & 0.9999 & 1160 & 0.9977 \\
$\mathrm{~Pb}\left({ }^{103} \mathrm{Rh}\right)$ & 0.1303 & 0.9998 & 0.1366 & 0.9979 \\
$\mathrm{Sb}$ & $1.04 \cdot 10^{-2}$ & 0.9996 & $1.07 \cdot 10^{-2}$ & 0.9974 \\
$\mathrm{~V}$ & 1057.8 & 0.9999 & 1154.2 & 0.9976 \\
$\mathrm{Zn}{ }^{a}$ & 13.1 & 1 & 13.77 & 1 \\
\hline
\end{tabular}

${ }^{\text {a }}$ determined by ICP OES.

\section{Sensitivity}

LODs were calculated as ( $3 \mathrm{SD} / \mathrm{m})$ and the of LOQs were calculated as $(10 \mathrm{SD} / \mathrm{m})$, where SD is the standard deviation of the blank signal $(n=11)$ and $m$ is the slope of the calibration line. Table IV shows the instrumental LODs and LOQs, in $\mu \mathrm{g} \mathrm{L}^{-1}$, as well as such limits referred to sample, considering the whole sample preparation process and analysis. Digested samples were analysed without dilution by ICP OES and were diluted ten times before the analysis by ICP-MS. The instrumental LODs by ICP OES were between $0.3 \mu \mathrm{g} \mathrm{L}^{-1}$ (for $\mathrm{Mg}$ ) and $1.5 \mu \mathrm{g} \mathrm{L}^{-1}$ (for Ca). Instrumental LODs from $2 \mathrm{ng} \mathrm{L}^{-1}$ (for Co, Mo and V) to $5.7 \mu \mathrm{g} \mathrm{L}^{-1}$ (for $\mathrm{Na}$ ) were obtained for ICP-MS. These limits can be improved using a higher volume of sample to carry out the digestion process. Moreover, the LOQs referred to the sample were lower than the MPLs established in the different regulations for $\mathrm{Pb}$ and $\mathrm{Cd}$ [3-6].

Table IV. Limits of detection (LODs) and quantification (LOQs) and analytical recovery (expressed as mean \pm standard deviation) for the elements determined by ICP OES or ICP-MS

\begin{tabular}{lccccc}
\hline Element & $\begin{array}{c}\mathbf{L O D}_{\mathrm{i}}^{\mathrm{b}} \\
\left(\mathbf{n g ~ L}^{-1}\right)\end{array}$ & $\begin{array}{c}\mathbf{L O Q}_{\mathrm{i}}^{\mathrm{b}} \\
\left(\mathbf{n g ~ L}^{-1}\right)\end{array}$ & $\begin{array}{c}\mathbf{L O D}_{\mathrm{s}}^{\mathrm{c}} \\
\left(\boldsymbol{\mu g} \mathrm{L}^{-1}\right)\end{array}$ & $\begin{array}{c}\mathbf{L O Q}_{\mathrm{s}}^{\mathrm{c}} \\
\left(\boldsymbol{\mu g} \mathbf{L}^{-1}\right)\end{array}$ & $\begin{array}{c}\text { Analytical } \\
\text { recovery }(\%)\end{array}$ \\
\hline $\mathrm{Al}$ & $1.0^{\mathrm{d}}$ & $3.3^{\mathrm{d}}$ & 98.7 & 329.0 & $89 \pm 1$ \\
$\mathrm{As}$ & 21.3 & 71.1 & 2.1 & 7.1 & $97 \pm 1$ \\
$\mathrm{Ca}^{\mathrm{a}}$ & $1.9^{\mathrm{d}}$ & $6.2^{\mathrm{d}}$ & 18.5 & 61.7 & $93 \pm 11$ \\
$\mathrm{Cd}$ & 5.2 & 17.2 & 0.5 & 1.7 & $103 \pm 1$ \\
$\mathrm{Co}$ & 2.3 & 7.6 & 0.2 & 0.8 & $102 \pm 1$ \\
$\mathrm{Cr}$ & 12.3 & 40.9 & 1.2 & 4.1 & $102 \pm 1$ \\
$\mathrm{Cu}$ & $0.2^{\mathrm{d}}$ & $0.7^{\mathrm{d}}$ & 21.6 & 72.2 & $99 \pm 1$ \\
$\mathrm{Fe}$ & 0.3 & $0.9^{\mathrm{d}}$ & 27.4 & 91.4 & $99 \pm 1$ \\
$\mathrm{Mg}$ & & $7.6^{\mathrm{d}}$ & 22.7 & 75.6 & $108 \pm 5$ \\
$\mathrm{Mn}$ & $2.3^{\mathrm{d}}$ & 12.2 & 0.4 & 1.2 & $97 \pm 2$ \\
$\mathrm{Mo}$ & 3.7 & 68.0 & 0.2 & 0.7 & $97 \pm 1$ \\
$\mathrm{Na}$ & 2.0 & $19.1^{\mathrm{d}}$ & 574.2 & 1913.9 & $89 \pm 1$ \\
\hline
\end{tabular}


de Souza, M. J. B.; Barciela-Alonso, M. C.; Aboal-Somoza, M.; Bermejo-Barrera, P.

Table IV. Limits of detection (LODs) and quantification (LOQs) and analytical recovery (expressed as mean \pm standard deviation) for the elements determined by ICP OES or ICP-MS (Continuation)

\begin{tabular}{|c|c|c|c|c|c|}
\hline Element & $\begin{array}{l}\operatorname{LOD}_{i}^{b} \\
\text { (ng L-1) }\end{array}$ & $\begin{array}{c}L^{L O Q_{i}^{b}} \\
\left(\mathrm{ng} \mathrm{L}^{-1}\right)\end{array}$ & $\begin{array}{l}\operatorname{LOD}_{\mathrm{s}}^{\mathrm{c}} \\
\left(\mu \mathrm{L}^{-1}\right)\end{array}$ & $\begin{array}{r}\operatorname{LOQ}_{\mathrm{s}}{ }^{\mathrm{c}} \\
\left(\mu \mathrm{g} \mathrm{L}^{-1}\right)\end{array}$ & $\begin{array}{c}\text { Analytical } \\
\text { recovery (\%) }\end{array}$ \\
\hline $\mathrm{Ni}$ & 27.5 & 91.6 & 2.7 & 9.2 & $98 \pm 1$ \\
\hline $\mathrm{Pb}$ & 33.4 & 111.4 & 3.3 & 11.1 & $100 \pm 1$ \\
\hline $\mathrm{Sb}$ & 16.1 & 53.8 & 1.6 & 5.4 & $93 \pm 1$ \\
\hline V & 2.3 & 7.5 & 0.2 & 0.8 & $102 \pm 1$ \\
\hline$Z n^{a}$ & $1.3^{d}$ & $4.3^{d}$ & 15.2 & 50.7 & $96 \pm 7$ \\
\hline
\end{tabular}

a determined by ICP OES; ' subscript "i" means "instrumental", i.e., instrumental LODs or instrumental LOQs; ' subscript "s" means "sample", i.e., LODs and LOQs referred to sample; ${ }^{d}$ expressed as $\mu \mathrm{g} \mathrm{L} \mathrm{L}^{-1}$.

The instrumental LODs obtained in this study were lower than those reported in previous studies $[7,10,28]$. Therefore, Pereira et al. [7] obtained LODs of $0.24,0.03,0.008$, and $0.056 \mathrm{mg} \mathrm{L}^{-1}$ for $\mathrm{Cr}, \mathrm{Cu}, \mathrm{Mg}$ and $\mathrm{Zn}$ determination by FAAS, $0.026 \mathrm{mg} \mathrm{L}^{-1}$ for $\mathrm{Na}$ by flame emission spectrometry and $0.99 \mu \mathrm{L} \mathrm{L}^{-1}$ for $\mathrm{Pb}$ determination by ETAAS. Coelho et al. [10], for element determination in juices samples by ICP OES and ICP-MS, achieved instrumental LODs of 0.07, 0.02, 0.08, 0,2, 0.1, 0.07, 0.1 and $1 \mathrm{\mu g} \mathrm{L}^{-1}$ for As, Cd, Co, $\mathrm{Cr}$, Mn, Mo, $\mathrm{Pb}$ and $\mathrm{Zn}$, respectively; and 0.01 and $0.12 \mathrm{mg} \mathrm{L}^{-1}$, for Fe and $\mathrm{Mn}$, respectively, whereas for $\mathrm{Cu}$ they obtained a similar LOD as the reported here. The method proposed in this work also shows better sensitivity for $\mathrm{As}, \mathrm{Ca}, \mathrm{Cd}, \mathrm{Co}, \mathrm{Cr}, \mathrm{Cu}, \mathrm{Fe}, \mathrm{Mn}, \mathrm{Mo}, \mathrm{Ni}, \mathrm{Pb}$ and $\mathrm{Sb}$ than those obtained by Savić et al. [8] for the analysis in orange juice samples. Hong et al. [9] reported LODs of 0.009, 0.017, 0.008, 0.941, 0.120, 0.051, 0.019, 0.081 and $0.176 \mu \mathrm{L} \mathrm{L}^{-1}$ for $\mathrm{As}, \mathrm{Cd}, \mathrm{Co}, \mathrm{Cr}, \mathrm{Cu}, \mathrm{Mn}, \mathrm{Pb}, \mathrm{V}$ and $\mathrm{Zn}$, respectively by ICP-MS, and $0.115,0.124,0.057$ and $0.058 \mu \mathrm{g} \mathrm{L}^{-1}$ for $\mathrm{Al}, \mathrm{Ca}, \mathrm{Fe}$ and $\mathrm{Mg}$ by ICP OES for element determination in citrus fruits samples.

\section{Precision and accuracy}

The precision of the method was studied in terms of repeatability and reproducibility. The repeatability was studied using a digested juice sample spiked with $10 \mathrm{\mu g} \mathrm{L}^{-1}$ and $10 \mathrm{mg} \mathrm{L}^{-1}$ for elements determined by ICP-MS and ICP OES, respectively. The relative standard deviation (RSD) was below $2 \%$ for all the elements studied. For reproducibility studies, samples were digested in triplicate and analysed in triplicate by ICP-MS and ICP OES. The RSDs obtained were lower than $10 \%$ for all the samples studied. Taking into account these results, it can be concluded that the method is precise.

The accuracy of the method was estimated using analytical recovery. Recovery percentages for $\mathrm{Ca}, \mathrm{Mg}$ and $\mathrm{Zn}$ were calculated using a digested juice sample spiked with element concentrations of $0.1,1$ and 10 $\mathrm{mg} \mathrm{L}^{-1}$. For the elements determined by ICP-MS the digested juice sample was spiked with concentrations of $0.5,10$ and $100 \mu \mathrm{g} \mathrm{L}^{-1}$. Analysis was carried out in quintuplicate for each concentration. The mean analytical recoveries (Table IV) were in a range from 89 to $108 \%$, Therefore, it can be concluded that the method presents a good recovery.

\section{Analysis of trace elements in juice samples}

The proposed method was applied to determine trace elements in 21 juice samples (previously described in "Samples" section). Aliquots of samples were subjected to microwave assisted acid digestion and analysis by ICP OES and ICP-MS. The digestion of the sample and also the analysis were carried out in triplicate.

The results obtained for minor trace elements are shown in Table V. According to those results, in the group of toxic elements, the levels of As and $\mathrm{Sb}$ were below the LODs $\left(2.1\right.$ and $1.6 \mu \mathrm{g} \mathrm{L}^{-1}$, respectively, see 
Table V) in all analysed samples and Pb was only detected in "Apple 1" juice sample, which contains 61.7 $\pm 7.2 \mu \mathrm{g} \mathrm{L}-1 \mathrm{~Pb}$. This $\mathrm{Pb}$ concentration is above current regulations, in which the maximum permitted limit is $0.03 \mathrm{mg} \mathrm{kg}^{-1}-0.05 \mathrm{mg} \mathrm{kg}^{-1}$ for fruit juices [3-6]. Cadmium was only quantified in "Apple 1" and "Pineapple 1 " juice samples with concentration of $2.6 \pm 0.1$ and $2.8 \pm 0.1 \mu \mathrm{g} \mathrm{L}^{-1}$, respectively. These Cd levels are far below the maximum permitted level established by the ANVISA [6] of $0.05 \mathrm{mg} \mathrm{kg}^{-1} \mathrm{Cd}$ for fruit juices and by European regulation [5], which establishes $0.02 \mathrm{mg} \mathrm{kg}^{-1}$ of $\mathrm{Cd}$ in drinks (including fruit juices) for infants and young children.

Co was detected in 13 of the 21 samples analysed. Co concentrations varied between $1.2 \mu \mathrm{g} \mathrm{L}^{-1}$ ("Orange 3") and $37.8 \mu \mathrm{g} \mathrm{L}^{-1}$ ("Passion fruit nectar"). Kiliç et al. [30] obtained Co concentrations of 1.6-17 $\mu \mathrm{g} \mathrm{L} \mathrm{L}^{-1}$ for orange and apricot juices, respectively.

Cr was detected in all the samples analysed except the orange juices "4" and " 5 " (juices squeezed in the laboratory). The $\mathrm{Cr}$ concentration varied between 3.1 and $18.9 \mu \mathrm{g} \mathrm{L}^{-1}$. Anastácio et al. [21] found $\mathrm{Cr}$ concentrations from 5.58-26.52 $\mu \mathrm{g} \mathrm{L}^{-1}$ in juices.

Cu was detected in 19 of the juices analysed with concentrations between $99.2 \mu \mathrm{L} \mathrm{L}^{-1}$ ("Apple juice 3") and $501.4 \mathrm{\mu g} \mathrm{L}^{-1}$ ("Pineapple"). These results are comparable to those obtained by Coelho et al. [10], who reported Cu concentrations of 69.8-79.1 $\mathrm{g} \mathrm{L}^{-1}$ (for apple juice), and $359 \mathrm{\mu g} \mathrm{L}^{-1}$ (for peach, apple and grape juice).

Mo was quantified in 20 samples in a concentration range from 0.8 ("Red berries" juice) to $5.9 \mu g \mathrm{~L}^{-1}$ ("Pineapple" juice). Savić et al. [8], found Mo concentrations of $0.34-0,48 \mathrm{mg} \mathrm{L}^{-1}$ in clear orange juice and, in a recent study, Demir et al. [23] reported Mo concentrations of $0.007 \mathrm{mg} \mathrm{L}^{-1}$ in apple and peach juice samples.

$\mathrm{Ni}$ was detected in 14 of the samples analysed and the concentrations obtained varied from of 16.6 to $113.9 \mu \mathrm{g} \mathrm{L}^{-1}$. The highest value was obtained for the "Passion fruit (nectar)" sample. Demir et al. [23] reported $\mathrm{Ni}$ concentrations of 0.018 and $0.003 \mathrm{mg} \mathrm{L}^{-1}$ in apricot and peach samples, respectively and concentrations below $0.018 \mathrm{mg} \mathrm{L}^{-1}$ for apple, orange, grape and cherry juice samples. Bora et al. [31] in the study of trace elements and heavy metals in fruit juices in the Romanian market, found Ni concentrations in a range between $13.85 \mu \mathrm{g} \mathrm{L}^{-1}$ (pear juice) and $72.83 \mu \mathrm{g} \mathrm{L}-1$ (kiwi juice).

$\mathrm{V}$ concentrations varied in a range between $11.7 \mu \mathrm{g} \mathrm{L}^{-1}$ ("Orange juice 3") and $91.4 \mu \mathrm{L} \mathrm{L}^{-1}$ (“Orange 1"), that are smaller values than those obtained by Gaiad et al. [32], who analysed 74 lemon juice samples and found mean $V$ levels of $0.15 \pm 0.02 \mu \mathrm{g} \mathrm{g}^{-1}$.

The concentrations obtained for major trace elements are included in Table VI. 
Table V. Concentration of minor trace elements in fruit juice and nectar samples (expressed as mean \pm standard deviation; $n=6$ )

\begin{tabular}{|c|c|c|c|c|c|c|c|c|c|}
\hline \multirow{2}{*}{ Sample } & \multicolumn{9}{|c|}{ Concentration $\left(\mu g \mathrm{~L}^{-1}\right)$} \\
\hline & As & $\mathrm{Cd}$ & Co & $\mathrm{Cr}$ & $\mathrm{Cu}$ & Mo & $\mathrm{Ni}$ & $\mathrm{Pb}$ & $\mathrm{Sb}$ \\
\hline Orange 1 & $<2.1$ & $<0.5$ & $1.5 \pm 0.1$ & $4.7 \pm 0.1$ & $<21.6$ & $2.70 \pm 0.03$ & $<2.7$ & $<3.3$ & $<1.6$ \\
\hline Orange 2 & $<2.1$ & $<0.5$ & $1.2 \pm 0.1$ & $6.0 \pm 0.4$ & $213 \pm 17$ & $2.96 \pm 0.04$ & $38.2 \pm 0.3$ & $<3.3$ & $<1.6$ \\
\hline Orange 3 & $<2.1$ & $<0.5$ & $1.2 \pm 0.1$ & $5.7 \pm 0.3$ & $218 \pm 12$ & $5.0 \pm 0.1$ & $<2.7$ & $<3.3$ & $<1.6$ \\
\hline Orange 4 & $<2.1$ & $<0.5$ & $<0.2$ & $<1.2$ & $293 \pm 12$ & $0.95 \pm 0.02$ & $48 \pm 3$ & $<3.3$ & $<1.6$ \\
\hline Orange 5 & $<2.1$ & $<0.5$ & $<0.2$ & $<1.2$ & $265 \pm 3$ & $1.7 \pm 0.1$ & $16.6 \pm 0.2$ & $<3.3$ & $<1.6$ \\
\hline Tangerine & $<2.1$ & $<0.5$ & $2.6 \pm 0.3$ & $4.9 \pm 0.4$ & $323 \pm 22$ & $2.9 \pm 0.2$ & $25 \pm 4$ & $<3.3$ & $<1.6$ \\
\hline Apple 1 & $<2.1$ & $2.6 \pm 0.1$ & $1.5 \pm 0.1$ & $9 \pm 1$ & $<21.6$ & $1.19 \pm 0.03$ & $<2.7$ & $62 \pm 7$ & $<1.6$ \\
\hline Apple 2 & $<2.1$ & $<0.5$ & $<0.2$ & $5.8 \pm 0.5$ & $122 \pm 10$ & $1.2 \pm 0.1$ & $<2.7$ & $<3.3$ & $<1.6$ \\
\hline Apple 3 & $<2.1$ & $<0.5$ & $1.2 \pm 0.1$ & $4.7 \pm 0.1$ & $99 \pm 3$ & $1.1 \pm 0.1$ & $<2.7$ & $<3.3$ & $<1.6$ \\
\hline Peach 1 & $<2.1$ & $<0.5$ & $<0.2$ & $10.3 \pm 0.7$ & $323 \pm 11$ & $4.5 \pm 0.1$ & $36 \pm 3$ & $<3.3$ & $<1.6$ \\
\hline Peach 2 & $<2.1$ & $<0.5$ & $<0.2$ & $4.4 \pm 0.2$ & $303 \pm 19$ & $3.8 \pm 0.1$ & $23.8 \pm 0.5$ & $<3.3$ & $<1.6$ \\
\hline Lemon & $<2.1$ & $<0.5$ & $<0.2$ & $3.1 \pm 0.3$ & $194 \pm 5$ & $0.9 \pm 0.1$ & $<2.7$ & $<3.3$ & $<1.6$ \\
\hline Pineapple 1 & $<2.1$ & $2.8 \pm 0.1$ & $7.4 \pm 0.4$ & $15.3 \pm 0.2$ & $172 \pm 9$ & $2.81 \pm 0.02$ & $84 \pm 5$ & $<3.3$ & $<1.6$ \\
\hline Pineapple 2 & $<2.1$ & $<0.5$ & $5.8 \pm 0.2$ & $19 \pm 1$ & $501 \pm 6$ & $5.9 \pm 0.1$ & $31 \pm 3$ & $<3.3$ & $<1.6$ \\
\hline Red berries & $<2.1$ & $<0.5$ & $1.5 \pm 0.2$ & $16.3 \pm 0.8$ & $130 \pm 7$ & $0.8 \pm 0.2$ & $<2.7$ & $<3.3$ & $<1.6$ \\
\hline Peach, apple and grape & $<2.1$ & $<0.5$ & $<0.2$ & $9 \pm 1$ & $376 \pm 17$ & $4.9 \pm 0.3$ & $29 \pm 1$ & $<3.3$ & $<1.6$ \\
\hline Mango and orange & $<2.1$ & $<0.5$ & $<0.2$ & $4.6 \pm 0.2$ & $149 \pm 5$ & $0.78 \pm 0.02$ & $27 \pm 1$ & $<3.3$ & $<1.6$ \\
\hline Pineapple, apple and grape 1 & $<2.1$ & $<0.5$ & $2.0 \pm 0.1$ & $19 \pm 2$ & $209 \pm 2$ & $4.3 \pm 0.1$ & $27 \pm 4$ & $<3.3$ & $<1.6$ \\
\hline Pineapple, apple and grape 2 & $<2.1$ & $<0.5$ & $5.8 \pm 0.3$ & $14 \pm 1$ & $189 \pm 5$ & $2.4 \pm 0.2$ & $66 \pm 4$ & $<3.3$ & $<1.6$ \\
\hline Passion fruit (nectar) & $<2.1$ & $<0.5$ & $38 \pm 2$ & $6.4 \pm 0.2$ & $140 \pm 9$ & $<0.2$ & $114 \pm 9$ & $<3.3$ & $<1.6$ \\
\hline Purple Pear (nectar) & $<2.1$ & $<0.5$ & $2.7 \pm 0.4$ & $4.9 \pm 0.3$ & $281 \pm 27$ & $2.079 \pm 0.001$ & $24 \pm 2$ & $<3.3$ & $<1.6$ \\
\hline
\end{tabular}


Table VI. Concentration of major trace elements in fruit juice and nectar samples (expressed as mean \pm standard deviation; $\mathrm{n}=6$ )

\begin{tabular}{|c|c|c|c|c|c|c|c|}
\hline \multirow{2}{*}{ Sample } & \multicolumn{7}{|c|}{ Concentration (mg L-1) } \\
\hline & Al & $\mathrm{Ca}$ & $\mathrm{Fe}$ & Mg & Mn & $\mathrm{Na}$ & $\mathrm{Zn}$ \\
\hline Orange 1 & $1.50 \pm 0.03$ & $97 \pm 1$ & $0.53 \pm 0.03$ & $46.2 \pm 0.4$ & $0.179 \pm 0.003$ & $28.5 \pm 0.4$ & $<0.015$ \\
\hline Orange 2 & $<0.098$ & $67 \pm 3$ & $0.44 \pm 0.07$ & $85 \pm 1$ & $0.16 \pm 0.02$ & $23.7 \pm 0.9$ & $0.139 \pm 0.001$ \\
\hline Orange 3 & $<0.098$ & $73.4 \pm 0.4$ & $0.57 \pm 0.01$ & $93 \pm 2$ & $0.16 \pm 0.01$ & $39.9 \pm 0.4$ & $0.22 \pm 0.02$ \\
\hline Orange 4 & $<0.098$ & $40 \pm 1$ & $0.39 \pm 0.02$ & $93.9 \pm 0.4$ & $0.139 \pm 0.003$ & $3.1 \pm 0.3$ & $0.4 \pm 0.1$ \\
\hline Orange 5 & $<0.098$ & $20.4 \pm 0.9$ & $0.35 \pm 0.01$ & $100.3 \pm 0.2$ & $0.114 \pm 0.001$ & $<0.6$ & $0.5 \pm 0.1$ \\
\hline Tangerine & $<0.098$ & $79 \pm 3$ & $0.44 \pm 0.01$ & $80 \pm 1$ & $0.201 \pm 0.005$ & $13 \pm 1$ & $0.18 \pm 0.01$ \\
\hline Apple 1 & $0.42 \pm 0.02$ & $54 \pm 2$ & $0.47 \pm 0.01$ & $48.3 \pm 0.6$ & $0.201 \pm 0.003$ & $15.2 \pm 0.2$ & $<0.015$ \\
\hline Apple 2 & $<0.098$ & $28 \pm 1$ & $<0.027$ & $34.5 \pm 0.3$ & $0.170 \pm 0.001$ & $21.8 \pm 0.4$ & $0.16 \pm 0.02$ \\
\hline Apple 3 & $<0.098$ & $35 \pm 3$ & $0.20 \pm 0.02$ & $38 \pm 1$ & $0.210 \pm 0.004$ & $3.3 \pm 0.2$ & $0.15 \pm 0.01$ \\
\hline Peach 1 & $<0.098$ & $25.2 \pm 0.4$ & $0.59 \pm 0.03$ & $33.9 \pm 0.9$ & $0.202 \pm 0.005$ & $7.2 \pm 0.5$ & $0.5 \pm 0.1$ \\
\hline Peach 2 & $<0.098$ & $22 \pm 2$ & $0.68 \pm 0.02$ & $37 \pm 2$ & $0.24 \pm 0.01$ & $14.6 \pm 0.5$ & $0.50 \pm 0.05$ \\
\hline Lemon & $<0.098$ & $10.9 \pm 0.5$ & $0.16 \pm 0.01$ & $53.3 \pm 0.2$ & $0.121 \pm 0.001$ & $9.4 \pm 0.6$ & $0.62 \pm 0.07$ \\
\hline Pineapple 1 & $<0.098$ & $64.0 \pm 0.2$ & $0.61 \pm 0.01$ & $72.4 \pm 0.7$ & $12.1 \pm 0.2$ & $12.5 \pm 0.1$ & $0.41 \pm 0.01$ \\
\hline Pineapple 2 & $0.60 \pm 0.02$ & $91 \pm 1$ & $1.81 \pm 0.03$ & $105 \pm 1$ & $11.90 \pm 0.04$ & $16.5 \pm 0.2$ & $0.98 \pm 0.01$ \\
\hline Red berries & $0.338 \pm 0.006$ & $30.9 \pm 0.7$ & $0.61 \pm 0.02$ & $17.5 \pm 0.2$ & $0.209 \pm 0.002$ & $17.9 \pm 0.5$ & $0.08 \pm 0.01$ \\
\hline Peach, apple and grape & $0.44 \pm 0.06$ & $41 \pm 1$ & $0.88 \pm 0.05$ & $48 \pm 2$ & $0.26 \pm 0.01$ & $8.5 \pm 0.2$ & $0.76 \pm 0.04$ \\
\hline Mango and orange & $<0.098$ & $31 \pm 2$ & $0.27 \pm 0.02$ & $33.0 \pm 0.5$ & $0.377 \pm 0.007$ & $27 \pm 1$ & $<0.015$ \\
\hline Pineapple, apple and grape 1 & $0.40 \pm 0.05$ & $68 \pm 2$ & $3.7 \pm 0.1$ & $84 \pm 2$ & $2.14 \pm 0.04$ & $24.7 \pm 0.4$ & $0.9 \pm 0.1$ \\
\hline Pineapple, apple and grape 2 & $0.40 \pm 0.01$ & $95.8 \pm 0.8$ & $1.07 \pm 0.04$ & $76 \pm 2$ & $7.1 \pm 0.2$ & $22 \pm 2$ & $0.4 \pm 0.1$ \\
\hline Passion fruit (nectar) & $<0.098$ & $10.2 \pm 0.6$ & $0.712 \pm 0.004$ & $26.7 \pm 0.6$ & $0.252 \pm 0.005$ & $21.7 \pm 0.4$ & $0.59 \pm 0.02$ \\
\hline Purple Pear (nectar) & $<0.098$ & $32.6 \pm 0.9$ & $0.28 \pm 0.01$ & $25.4 \pm 0.4$ & $0.156 \pm 0.003$ & $11.8 \pm 0.6$ & $0.39 \pm 0.01$ \\
\hline
\end{tabular}


Among the major trace elements, $\mathrm{Ca}$ and $\mathrm{Mg}$ are the ones found at the highest concentrations, followed by $\mathrm{Na}$. The concentrations of these elements vary from 10.2 to $96.5 \mathrm{mg} \mathrm{L}^{-1}$ for Ca, 17.5 to $104.7 \mathrm{mg} \mathrm{L}^{-1}$ for $\mathrm{Mg}$ and from 1.9 to $28.5 \mathrm{mg} \mathrm{L}^{-1}$ for $\mathrm{Na}$. The highest $\mathrm{Mg}$ concentrations were found in pineapple juices, orange juices, tangerine juice and juices prepared by mixing pineapple, apple, and grape juices. The lowest concentration was found in red berries juice. Similar behavior was observed for $\mathrm{Ca}$, but in this case the lowest concentration was found in the "Passion fruit (nectar)" sample (10.2 mg L-1); moreover, there was lower concentration in the orange juices squeezed in the laboratory (20.4 and $39.7 \mathrm{mg} \mathrm{L}^{-1}$ for "Orange 5 " and "Orange 4", respectively) than in the ones acquired in the supermarket and commercialized in tetra pack. The lowest $\mathrm{Na}$ concentration was also found in the orange juices squeezed in the laboratory. The values are smaller than the values obtained by Musa and Lal [19]: 33.8-638.7 $\mathrm{mg} \mathrm{kg}^{-1}$ for Ca and 17.0$1281.8 \mathrm{mg} \mathrm{kg}^{-1}$ for $\mathrm{Na}$ in several juices (apple, orange, mango, multifruit, pulpy orange and aam panna) and the results obtained by Ekşi and Kirtiş [33] who reported concentration ranges from 75 to $160 \mathrm{mg} \mathrm{L}^{-1}$ Mg in 103 different sour cherry juice samples.

Al was only quantified in seven of the 21 samples analyzed, with concentrations of $0.4-1.5 \mathrm{mg} \mathrm{L}^{-1}$. The lowest Al content was measured in "Pineapple, apple and grape 1" juice $\left(0.4 \mathrm{mg} \mathrm{L}^{-1}\right)$ and the highest in "Orange 1" (1,5 mg L-1). Kowalska et al. [12] found concentrations of 0.462-6.646 mg kg-1 in orange juice and black currant nectars, respectively. These authors suggest that the packaging of food products can have an impact on the level of trace elements in juices, since fruit juices and nectars stored in tetra pack packaging were characterised for a high concentration of Al.

Fe was quantified in 20 of the 21 samples analysed and its concentration varied from 0.16 to $3.7 \mathrm{mg} \mathrm{L}^{-1}$. The highest Fe concentration was also found in the multifruit juice containing pineapple ("Pineapple, apple and grape 1") and in "Pineapple 2" juice sample. These concentrations are higher than those obtained by Demir et al. [23], who observed Fe levels between $0.066 \mathrm{mg} \mathrm{L}^{-1}$ (orange nectar) and $0.894 \mathrm{mg} \mathrm{L}^{-1}$ (apricot nectar) for juices samples purchased in Istanbul. Mohamed et al. [28] found Fe concentrations fruit juices purchased in a Yemeni market of 0.04-11.5 $\mathrm{mg} \mathrm{L}^{-1}$.

Mn was quantified in all the samples analyzed, with concentrations from 0.114 to $12 \mathrm{mg} \mathrm{L}^{-1}$. The highest concentrations were found in pineapples and multifruit juices containing pineapple. These values are in accordance with those obtained by Coelho et al. [10] (190-9220 $\left.\mu \mathrm{g} \mathrm{L}^{-1}\right)$ in fruit juices and by Rocha et al. [34] (116-3296 $\mathrm{g} \mathrm{L} \mathrm{L}^{-1}$ ) in orange and grape juices and nectars (orange, mango, passion fruit, peach and grape).

Finally, $\mathrm{Zn}$ was quantified in 18 of 21 of samples analyzed and the concentrations varied from 0.08 to $0.9 \mathrm{mg} \mathrm{L}^{-1}$. These results agree with those found by Coelho et al. [10].

The differences observed among the concentrations of these elements in the samples analysed, could be attributed to different factors such as metal cation exchange capacity and soil $\mathrm{pH}$, fungi presence, different species of the same plant, geographical and climatic variability conditions as well the industrial production process applied and packaging material. To investigate these differences further, data were subjected to exploratory multivariate analysis techniques, namely, PCA and CA (Principal Component Analysis and Cluster Analysis, respectively). The results -not included here- were inconclusive, since no groups of samples were revealed on the basis of their elemental contents, in spite of the different raw materials (i.e., fruits) used for their manufacture. Maybe that the manufacture process of the juices itself covers up such differences in the final products.

\section{CONCLUSIONS}

According to the results obtained, the determination of trace elements in fruit juices by ICP OES and ICP-MS provides good sensitivity, precision, analytical recovery, and it is easy to implement in laboratories for routine analysis. The proposed method provides certain advantages, such as reduction of volume of reagents (nitric acid) and time require for sample preparation, larger number on analytes determined and higher sensitivity for most of the elements. 
In the juices analyzed, toxic trace elements like $\mathrm{As}$ and $\mathrm{Sb}$ were not detected and only in one apple juice was found a content of $61.7 \mu \mathrm{g} \mathrm{L}^{-1}$ of $\mathrm{Pb}$, which is above of the current regulations. Cd was only quantified in two of the samples analyzed with values below the maximum permitted level established by the ANVISA and European regulations. In addition, essential elements such as $\mathrm{Ca}, \mathrm{Mg}$ and $\mathrm{Na}$ were in high concentrations in the samples analyzed. Considering the results obtained in this study, we can conclude that fruit juices are a good source of essential elements for humans, and the presence of toxic elements do not pose a risk for human health. However, further studies will be necessary to evaluate the bioavailability of these trace elements.

\section{Conflicts of interest}

The authors declare that the conclusions achieved are supported by the data included in this paper. Of course, raw data are available from the corresponding author on request.

The authors declare that there are no conflicts of interest between them, affiliations, funding, financial or management relationships.

\section{Acknowledgements}

Financial support for this study was provided by the autonomous regional government Xunta de Galicia [Grupo de Referencia Competitiva ED431C2018/19], as well as by the Consellería de Educación Programme for the Development of Strategic Grouping in Materials - AEMAT at the University of Santiago de Compostela [Grant No. ED431E2018/08 (also from the Xunta de Galicia)]. Both grants were co-funded by the European Regional Development Fund (from the European Union).

\section{REFERENCES}

1. WHO/FAO. WHO Technical Report 916: Diet, Nutrition and the Prevention of Chronic Diseases, 2003. Available at: https://www.fao.org/3/ac911e/ac911e00.htm [Accessed July 2021].

2. Silva E. P.; Abreu, W. C.; Gonçalves, O. A; Damiani, C.; Vilas Boas, E. V. B. Food Sci. Technol., 2017, 37 (1), pp 13-18 (https://doi.org/10.1590/1678-457X.0107).

3. FAO/WHO. Codex Alimentarius, General Standard for Contaminants and Toxins in Food and Feed, Codex Standard CXS 193-1995, 2019. Available at: https://www.fao.org/fao-who-codexalimentarius/ codex-texts/list-standards/en/ [Accessed July 2021].

4. European Commission (EC). Commision Regulation (EU) 2021/1317 of 9 August 2021 amending Regulation (EC) No 1881/2006 as regards maximum levels of lead in certain foodstuffs (Text with EEA relevance), Official Journal of the European Union, L 286, 10.8.2021, pp 1-4. Available at: https://eurlex.europa.eu/eli/reg/2021/1317/oj [Accessed July 2021].

5. European Commission (EC). Commision Regulation (EU) 2021/1323 of 10 August 2021 amending Regulation (EC) No 1881/2006 as regards maximum levels of cadmium in certain foodstuffs (Text with EEA relevance), Official Journal of the European Union, L 288, 11.8.2021, pp 13-18. Available at: https://eur-lex.europa.eu/eli/reg/2021/1323/oj [Accessed July 2021].

6. Brazilian Health Regulatory Agency (ANVISA). Instrução Normativa - IN n. ${ }^{\circ} 88$ de 26/03/2021, Diário Oficial da União da República Federativa do Brasil, 31/03/2021, n. ${ }^{\circ} 61$, pp 225-234. Avaliable at http:// antigo.anvisa.gov.br/legislacao\#/visualizar/447078. [Accessed October 2021].

7. Pereira, C. C.; Souza, A. O.; Oreste, E. Q.; Vieira, M. A.; Ribeiro, A. S. Food Chem., 2018, 240, pp 959-964 (https://doi.org/10.1016/j.foodchem.2017.07.112).

8. Savić, S. R.; Petrović, S. M.; Stamenković, J. J.; Petronijević, Ž. B. Advanced Technologies, 2015, 4 (2), pp 71-78. Available here [Accessed September 2021].

9. Hong, Y. S.; Choi, J. Y.; Nho, E.; Hwang, I. M.; Khan, N.; Jamila, N.; Kim, K. S. J. Sci. Food Agric., 2019, 99, pp 1870-1879 (https://doi.org/10.1002/jsfa.9382).

10. Coelho, I.; Rego, A.; Gueifão, S.; Nascimento; A. C.; Castanheira, I. J. Chemometr., 2017, 31, e2868, (https://doi.org/10.1002/cem.2868). 
11. Goosen, N. J.; Oosthuizen, D.; Stander, M. A.; Ibrahim, A. D.; Pedavoah, M. M.; Usman, G. O. South African J. Botany, 2018, 119, pp 11-16 (https://doi.org/10.1016/j.sajb.2018.08.008).

12. Kowalska, G.; Pankiewicz, U.; Kowalski, R.; Mazurek, A. Open Chem., 2020, 18, pp 443-452 (https:// doi.org/10.1515/chem-2020-0043).

13. Wang, W.; Jackson, L.; Jablonski, J. E. J. Food Prot., 2017, 80, pp 892-902 (https://doi.org/10.4315/0362028X.JFP-16-464).

14. Pinheiro, F. C.; Amaral, D. B. C.; Schiavo, D.; Nóbrega, J. A. Food Anal. Methods, 2017, 10, pp 992998 (https://doi.org/10.1007/s12161-016-0663-7).

15. Hafez, E. M.; El Sheikh, R.; Fathallah, M.; Sayqal, A. A.; Gouda, A. A. Microchem. J., 2019, 150, 104100 (https://doi.org/10.1016/j.microc.2019.104100).

16. Jedryczko, D.; Pohl, P.; Welna, M. Food Chem., 2017, 225, pp 220-229 (https://doi.org/10.1016/j. foodchem.2016.12.092).

17. Jamil, D. M. Al-Nahrain J. Sci., 2018, 21 (1), pp 23-26 (https://doi.org/10.22401/JUNS.21.1.04).

18. Bonomelli, C.; Arias, M. I.; Villalobos, L. Commun. Soil Sci. Plant Anal., 2018, 49 (6), pp 735-744 (https://doi.org/10.1080/00103624.2018.1435681).

19. Rahim, M.; Saqib, N. U.; Wahid, F.; Khan, N.; Alrawi, L. I. J. Phys. Sci., 2020, 31 (2), pp 61-73 (https:// doi.org/10.21315/jps2020.31.2.5).

20. Li, F.-K.; Gong, A.-J.; Quu, L.-N.; Zhang, W.-W.; Li, J.-R.; Liu, Y.; Li, J.-D.; Gao, G.; Yuan, X.-T. Microchem. J., 2019, 147, pp 93-101 (https://doi.org/10.1016/j.microc.2019.02.060).

21. Anastácio, M.; Santos, A. P. M.; Aschner, M.; Mateus, L. Toxicol. Rep., 2018, 5, pp 434-439 (https://doi. org/10.1016/j.toxrep.2018.03.010).

22. Fathabad, A. E.; Shariatifar, N.; Moazzen, M.; Nazmara, S.; Fakhri, Y.; Alimohammadi, M.; Azari, A.; Khaneghah, A. M. Food Chem. Toxicol., 2018, 115, pp 436-446 (https://doi.org/10.1016/j. fct.2018.03.044).

23. Demir, F.; Kipcak, A. S.; Ozdemir, O. D.; Derun, E. M. J. Food Sci. Technol., 2020, 57, pp 4432-4442 (https://doi.org/10.1007/s13197-020-04480-9).

24. Dewi, F.; Sim, L. P.; Wang, J.; Tong, G. M. K.; Shin, R. Y. C.; Lee, T. K. Int. J. Mass Spectrom., 2016, 411, pp 14-20 (https://doi.org/10.1016/j.jms.2016.11.001).

25. Schmutzer, G. R.; Dehelean, A.; Magdas, D. A.; Cristea, G.; Voica, C. Anal. Lett., 2016, 49 (16) (https:// doi.org/10.1080/00032719.2015.1130713).

26. Darkwah, G.; Brewoo, G. A.; Barimah, J.; Sampson, G. O.; Abe-Inge, V. Sci. African, 2020, 8, e00341 (https://doi.org/10.1016/j.sciaf.2020.e00341).

27. Paula, F. J. A.; Guiné, R. P. F.; Cruz-Lopes, L.; Duarte, A. C; Fragata, A. O. S.; Reis, M. A. L. Czech J. Food Sci., 2015, 33 (4), 384-391 (https://doi.org/10.17221/531/2014-CJFS).

28. Mohamed, F.; Guillaume, D.; Abdulwali, N.; Al-Hadrami, K. Maqtari, M. A. A. Heliyon, 2020, 6, e04908 (https://doi.org/10.1016/j.heliyon.2020.e04908).

29. Massart, D. L.; Vandeginste, B. G. M.; Buydens, L. M. C.; De Jong, S.; Lewi, P. J.; Smeyers-Verbeke, J. Handbook of Chemometrics and Qualimetrics: Part A. Elsevier, Amsterdam, 1998, Chapter 8, pp 171-230 (https://doi.org/10.1016/S0922-3487(97)80038-X).

30. Kılıç, S.; Yenisoy-Karakaş, S.; Kılıç, M. Food Anal. Methods, 2015, 8, pp 2487-2495 (https://doi. org/10.1007/s12161-015-0136-4).

31. Bora, F. D.; Călugăr, A.; Bunea, C. I.; Racz, I. Bull. UASVM Horticulture, 2020, 77 (2), pp 125-128 (https://doi.org/10.15835/buasvmcn-hort:2020.0022).

32. Gaiad, J. E.; Hidalgo, M. J.; Villafañe, R. N.; Marchevsky, E. J.; Pellerano, R. G. Microchem. J., 2016, 129, pp 243-248 (https://doi.org/10.1016/j.microc.2016.07.002)

33. Ekşi, A.; Kirtiş, E. B. U. Eur. J. Food Sci. Technol., 2016, 4 (1), pp 52-60. Available here [Accessed September 2021].

34. Rocha, P. S. M.; Cruz, G. F. B.; Cassella, R. J. J. Anal. Methods Chem., 2020, Article ID 8816068 (https://doi.org/10.1155/2020/8816068). 